\title{
VISSZATEKINTÉS A KREATÍV OSZTÁLY ELMÉLETÉRE
}

\author{
EGEDY TAMÁS \\ RETROSPECTIVE ANALYSIS OF THE CREATIVE CLASS CONCEPT
}

\begin{abstract}
One of the defining concepts of neoliberal economic policy in the 2000s was the creative class theory of Richard Florida. The theory has drawn attention to the economic role and importance of creative workers and has been a focal point for urban politicians in developing urban development policies and strategies. The main aim of this study is to introduce the most important milestones in the development of the theory and to present the socio-geographical and labor market characteristics of the creative class. In this study, I have attempted to summarize all the defining theoretical foundations, findings, and critiques that have accompanied the development and history of the creative class concept. The theoretical paper is based on the processing and evaluation of domestic and international literature.
\end{abstract}

Keywords: creative class, Richard Florida, coworking, Digital Taylorism

\section{Bevezetés}

A globalizáció erősödésével párhuzamosan az elmúlt évtizedekben egy új társadalmi rend, az információ és tudás társadalma jelent meg, amelyben a tudás, a kreativitás és az innováció megléte vált elengedhetetlenül fontos versenyképességi tényezóvé. Az ipari társadalom megszúnik és fokozatosan átadja helyét az információs- és tudástársadalomnak. Az új informatikai eszközök olyan társadalmi változásokat indítottak el, amelyek átalakítják a társadalom szerkezetét, a hatalmi viszonyokat és a munka világát. A 20. század második felében az információs társadalom kifejezést egyre inkább felváltotta a tudástársadalom kifejezés, amelyet Európában elsők között Nagy-Britanniában használtak a 2000-es évek elején. Előtérbe került tehát az információ és a tudás szerepe, amivel párhuzamosan viszont új tudományos kérdések is felmerültek. Jellemezhető-e egy társadalom a korszakra leginkább jellemző technikai vívmányokkal? Az információ, vagy a tudás megszerzése kerül-e inkább előtérbe? Melyik megszerzésének a képessége juttatja az egyéneket, vállalatokat nagyobb versenyelőnyhöz? A posztindusztriális gazdasági fejlódés azonban elsodorta ezeket a kérdéseket, s KAO J. (1999) szerint már nem a tudás vagy az információ, hanem a kreativitás korát éljük és a kreativitás az a tényezó, amely még inkább megnöveli a tudás hasznosságát és értékét. FLORIDA, R. (2002) még ennél is tovább ment és kreatív társadalomról beszélt, amelynek a kezében az információ és a tudás csak eszközként jelenik meg. A globalizáció úttörése, a termelő társadalom egyfajta háttérbe szorulása, a technológiai forradalom térnyerése, az információn és tudáson alapuló társadalom megjelenése mind-mind maga után vonta egy új társadalmi rend kialakulását, amelyben a meglévő kulcskompetenciák mellett új tényezők kaptak helyet. Ilyen tényezőnek tekintjük a kreativitást, amely napjainkban már nem csak a géniuszok kiváltsága, hanem mindennapi életünk szerves részévé vált. Ebben az új társadalmi rendben meghatározó szerepet játszik a kreatív osztály. Jelen elméleti tanulmány célja, hogy a kreatív osztály teóriájának kialakulását és fejlődését bemutassa, s legfontosabb mérföldköveit és hatásait áttekintse. A tanulmány első részében a kreatív osztály elméletének alaptéziseit és jellemzőit veszem számba, a második felében munkaerőpiaci jellemzőket vizsgálok, 
majd a harmadik részben összefoglalom az elmélettel kapcsolatos legfontosabb kritikákat. A tanulmányban kiemelt hangsúlyt helyezek a társadalomföldrajzi és városföldrajzi kapcsolatok feltárására. Az írás alapvetően a kreatív osztály elméletére fókuszál és nem célja az elmélettel szorosan összefüggő kreatív város, kreatív ipar és okos város koncepcióinak bemutatása.

\section{A kreatív osztály elméletének társadalomföldrajzi hatásai}

\section{A kreatív osztály elméletének alapjai}

2002 mérföldkő volt a kreatív gazdaság történetében, RICHARD FLORIDA ugyanis ekkor publikálta elméletét a kreatív osztályról (FLORIDA, R. 2002). A kreatív gazdaság alapvetôen munkaerő-igényes iparágakból áll, ahol a kreatív folyamatok eredményessége nagyban függ azoktól, akik az adott folyamatokat végzik. Az értékteremtés nem gépeken, hanem az embereken keresztül történik, így fontos megvizsgálni, hogy kik dolgoznak a kreatív gazdaságban. Florida nem határoz meg egyértelmú definíciót a kreatív gazdaság fogalmára, ellenben kihangsúlyozza, hogy a tudás- és információs társadalom alárendeli magát a kreativitásnak, amely a gazdaság hajtóerejévé válik. Pontosabban a kreatív munkaeró válik a gazdaság motorjává. Florida megközelítésében tehát a fő szerepet nem a gazdaság maga, hanem a kreatív emberek összessége, az úgynevezett kreatív osztály játssza. Elméletében tulajdonképpen az üzleti környezet helyett az emberi környezetre helyezte át a hangsúlyt.

Florida a kreatív osztályt két részre bontotta: Van az úgynevezett szuper kreatív mag, amelybe mindenki besorolható, aki olyan új gondolatokat, formákat, technológiát vagy akár szolgáltatást hoz létre, amelyek átruházhatók és széles körben használhatók. Ebbe a csoportba sorolja például a filmkészítóket, a szoftveriparban dolgozókat, kutatókat, múvészeket, írókat, építészeket. A másik kategória a kreatív szakemberek köre, akik tudásalapú iparágakban dolgoznak és a kreatív problémamegoldás az elsődleges feladatuk, ami nagyfokú önállóságot és magas képzettséget igényel. Ebbe a csoportba tartoznak például a high-tech szektorban és a pénzügyi szolgáltatási szektorban dolgozók (FLORIDA, R. 2002). Florida szerint a kreatív osztály tagja a szerint lehet valaki, hogy milyen munkakört tölt be, konkrétan mivel foglalkozik (kemény besorolási faktor), illetve a kreatív osztály tagjai külön ideológiával, sajátos értékrenddel rendelkeznek (puha besorolási faktor). Ilyen puha tényezők lehetnek például az individualitás fontossága, a non-konform viselkedési formák előtérbe helyezése, a saját érdemek hangsúlyozása, valamint a sokszínúség támogatása, a mások iránti nyitottság. A kreatív osztály tagjai a tehetség, a technológiai jártasság és a tolerancia (3T) magas szintje alapján határolhatók el a többi társadalmi csoporttól, e három tényező együtt egyértelmúen a kreatív osztály jellemzője. A kreatív osztály tagjai munkájuk során alapvetóen háromféle tudásbázist használnak: a) a szintetikus tudást, vagyis a már meglévő ismeretek újszerú kombinációját, gyakorlatias tevékenységek elsajátítását; b) az analitikus tudást, vagyis formális modellek, tudományos elvek, racionális eljárások alkalmazását; c) a szimbolikus tudást, amely nem a tudományos tudásteremtéshez, hanem sokkal inkább a múvészi alkotáshoz, illetve a kreatív iparágakhoz kötődik (LENGYEL B.-SÁGVÁRI B. 2009). A háromféle tudásbázis alapján a kreatív osztály viszonylag jól körülhatárolható (1.ábra).

A kreatív osztály fogalma az új évezred hajnalán jelent meg, azóta viszont folyamatosan formálódott és egyre jobban kirajzolódott azok köre, akik ténylegesen ebbe a kategóriába sorolhatók. A kérdés eldöntésére kiválóan alkalmas a kreatív trident elv, amely a kemény és puha besorolási tényezóket is figyelembe véve 3 csoportja osztja a kreatív 


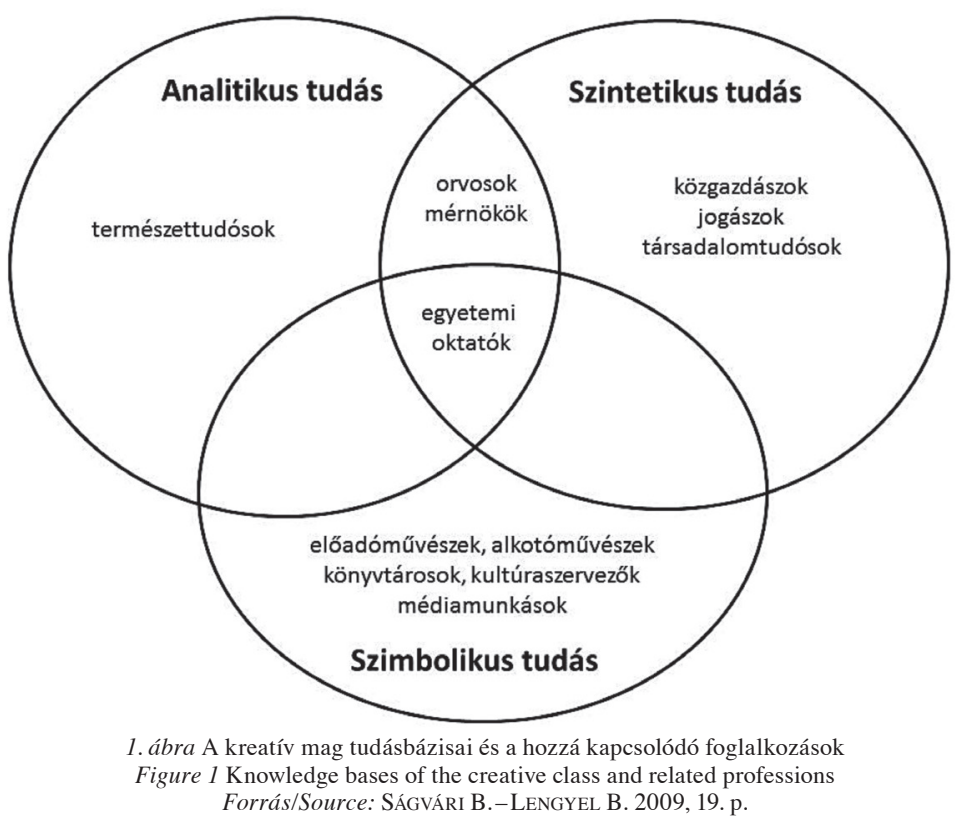

osztályt: kreatív iparágakban tevékeny kreatív szakemberek, nem kreatív iparágakban tevékeny kreatív szakemberek és támogató személyzet a kreatív iparágakban. A kreatív trident elv segítségével megteremthetjük a kapcsolatot a kreatív iparágakban dolgozó kreatív dolgozók és a nem kreatív iparágban dolgozó, de kreatív munkát végző munkaerő között. A modell kifejlesztésének elsődleges célja a következő volt: úgy vegye számba a kreatív tevékenységeket végzőket és a kreatív iparban dolgozókat, hogy az statisztikailag elemezhetó legyen (tehát ne legyenek benne ismétlések és átfedések). A modell a foglalkoztatások három típusát különbözteti meg:

- Specialisták, vagyis olyan kreatív foglalkozásúak, akik a kreatív iparágakban dolgoznak (pl. múvészek, szakemberek és kreatív egyének).

- Támogató személyzet, vagyis akik a kreatív iparágakban dolgoznak, de nem kreatív pozíciót töltenek be (pl. irányítási, adminisztrációs és számviteli háttérmunkaerô);

- Kreatív foglalkozásúak, akik a nem kreatívként definiált iparágakba „beágyazódva” dolgoznak (HigGs, P. et al. 2008).

A kreatív trident elv a Florida-féle besoroláshoz némiképp hasonlóan, kettős mércét használ a kreatív osztály meghatározására. Akik a kreatív trident elv szerint akár a kreatív iparágakban, akár azokon kívül kreatív foglalkozást végeznek, megfeleltethetôk a Florida-féle kemény besorolási faktorok alapján felállított kreatív osztálynak, míg a támogató személyzet, akik ugyan nem kreatív munkát végeznek, valószínúleg rendelkeznek a Florida által meghatározott puha besorolási tényezőkkel.

Florida hangsúlyozta, hogy a városok akkor lehetnek sikeresek és versenyképesek, ha a kreatív osztály tagjainak vonzására fókuszálnak és olyan társadalmi és gazdasági környezetet teremtenek, amely elősegíti a kreatív osztály letelepedését. Ebben kiemelt szerepe van a puha telepítőtényezőknek.

A kreatív osztály nagyságáról szólva elmondhatjuk, hogy 2006-ban körülbelül 6,5 millió kreatív dolgozó volt Európában (a foglalkoztatottak 2,7\%-a). A kreatív osztály legnagyobb arányát Szingapúrban mérték (52\%), emellett Korea (47\%), Ausztrália (45\%) és Kanada 
(43\%) rendelkezik még jelentősebb kreatív munkaerővel (ERNST-YouNG 2015). Ezen államok a globális kreativitási index (GCI) ranglistáján is előkelő pozícióval rendelkeznek. A legtöbb európai országban 2-4\% között van a kreatív foglalkoztatottak aránya. Legmagasabb a kreatívok aránya a fôvárosokban és a regionális centrumokban: például Spanyolországban, Barcelonában kb. 45\%, Olaszországban, Rómában és Milánóban 35\%, Svédországban Stockholmban 30\%, Romániában Bukarestben 42,6\%, Csehországban Prágában $40 \%$ a kulturális és kreatív iparágakban foglalkoztatottak aránya. A kelet-európai országokban általában alacsonyabb a kreatívok aránya a foglalkoztatottak között (SLACH, O. et al. 2013).

\section{A kreatív osztály lokalizációjának gazdasági és földrajzi alapjai}

Jogosan fogalmazódik meg a kérdés, hogy hol található a kreatív osztály? A kérdéshez piacgazdasági és földrajzi oldalról is közelíthetünk. CLIFTON, N. és munkatársai (2012) mélyrehatóan vizsgálták a kreatív osztály előfordulásának jellemzőit koordinált és liberális piacgazdaságban (1. táblázat). A svéd és az egyesült királyságbeli kreatív osztály lokalizációját kutatva megállapították, hogy a kreatív osztály egészének, csoportjainak (kreatív mag és kreatív dolgozók), valamint általában a tehetségnek a jelenléte a koordinált és liberális piacgazdaságban valamelyest eltér. A kreatív osztály egészére, illetve a kreatív dolgozókra és a tehetségre igaznak bizonyult azon feltételezésük, hogy ezek egyenletesebben oszlanak el a koordinált piacgazdaságban, mint a liberális piacgazdaságban, vagyis

1. táblázat - Table 1

A kreatív osztály jellemzői a koordinált és a liberális piacgazdaságban

Characteristics of creative class in co-ordinated and liberal market economies

\section{Hipotézisek}

Kreatív Kreatív Kreatív Tehetség
osztály mag dolgozók

A kreatív osztály egyenletesebben oszlik el a koordinált piacgazdaságban (KPG) mint a liberális piacgazdaságban (LPG)

A kreatív osztály jelenléte jobban társítható a foglalkoztatás növekedésével LPG-ben, mint KPG-ben A kreatív osztály jelenléte jobban társítható a népesség növekedésével LPG-ben, mint KPG-ben

A kreatív osztály jelenléte jobban társítható a high-tech foglalkoztatás növekedésével LPG-ben, mint KPG-ben

A kreatív osztály lokalizációja és az új cégek alapítása között szorosabb az összefüggés LPG-ben, mint KPG-ben

A kreatív osztály elhelyezkedése inkább társítható a munkanélküliséggel LPG-ban, mint KPG-ben

A kreatív osztály elhelyezkedése inkább társítható a hely minőségével (diverzitás és kulturális osztály mag dolgozók

lehetőségek értelemben) LPG-ben, mint KPG-ben

$\begin{array}{cccc}+ & - & + & + \\ + & + & - & - \\ - & - & - & - \\ + & + & + & - \\ + & + & + & + \\ + & + & + & + \\ +/- & +/- & +/- & +/-\end{array}$

Forrás/Source: Clifton, N. et al. 2012; 12 p.

+ a hipotézis igaznak bizonyult; - a hipotézis nem bizonyult igaznak 
a liberális piacgazdaság magában hordozza a kreatív osztály nagyobb fokú koncentrációját. A liberális piacgazdaságban mind a négy kategória lokalizációja szoros összefüggést mutat az új cégek alapításával. Itt előre utalnék Florida kreatív osztály elméletének azon éles kritikájára, miszerint nem a kreatív dolgozókat, hanem sokkal inkább a kreatív cégeket kell vonzani a városba ahhoz, hogy annak versenyképessége növekedjen. Nagy hatással bír a high-tech munkahelyek jelenléte a kreatív osztály lokalizációjára, ugyanakkor a népesség növekedése egy városban kevésbé befolyásolja a kreativitás, a kreatív tevékenységek és a kreatív munka jelenlétét. A hely minőségének (vagyis a Florida által favorizált puha tényezőknek) a kiemelt szerepe a kreatív osztály lokalizációjában kétséges, rendkívüil változó képet mutat, ami a vizsgált kategóriák összetettségére, változatosságára irányítja rá a figyelmet. A kreatív osztály kritikájában egyértelmúen visszaköszön majd az is, hogy a kreatív osztály rendkívül összetett és igazándiból nem értelmezhető egységes osztályként.

STOLARICK, K. és CURRID-HALKETT, E. (2013) arra a következtetésre jutottak amerikai városok vizsgálatával, hogy a kreatív munkaerô pozitívan hat a gazdasági aktivitásra és a munkanélküliségre, a kisebb városokban (100 ezer fó alatt) viszont a munkásosztály jelentósége meghaladja a kreatív osztályét. Azokban az alacsonyabb népességú városokban, ahol a kereskedelem és a feldolgozóipar jelentősebb szerepet játszik, a munkásosztály jelenléte csökkentette a munkanélküliséget (vagyis pozitívan hatott a foglalkoztatásra). A munkásosztály száma és összetétele hosszú távon sokkal stabilabb, mint a kreatív osztályé, így a kreatív osztály a nagy fluktuációja miatt destabilizáló tényezőként is feltûnhet a helyi gazdaságban.

STORPER, M. és SCOTT, A. J. (2009) megállapították, hogy a városi gazdaság növekedése szorosan kapcsolódik a termelés gazdaságföldrajzi jellemzőihez, illetve a cégek és a munkaerő mozgásához. BoschMA, R. és FRITSCH, M. (2009) pozitív összefüggést találtak a kreatív osztály, a foglalkoztatás növekedése, a tolerancia és a nyitottság, valamint a kreatívok magasan urbanizált régiókba kötözése között. MCGRANAHAN, D. és WoJAN, T (2005) is vizsgálták, hogy a kreatív osztály koncepciója csak városi, vagy vidéki körülmények között is működik-e, tehát a rurális térségek is vonzanak-e kreatív dolgozókat? Eredményeik szerint a vidéki térségekben is pozitív kapcsolat áll fenn a kreatív dolgozók foglalkoztatottsága és a foglalkoztatottság növekedése között.

A kreatív osztály munkahely- és lakóhelyválasztási preferenciáit vizsgáló kutatások egyértelmúen bizonyították, hogy az életminőség rendkívül fontos tényező a kreatívok számára (ZANDIATASHBAR, A. et al. 2019). Ennek fontos részét képezi a napi ingázás, ami egyre nagyobb szerepet kap a kreatívok mindennapi életében. Az ingázás különösen azon iparágak esetében kerül előtérbe, amelyek térhez kötöttek (a high-tech cégek második típusa), míg azon cégek esetében, amelyeknél a földrajzi tér jelentôsége elhanyagolható (high-tech cégek első típusa), a dolgozókat gyakran részmunkaidőben, rugalmas távmunka keretében foglalkoztatják. Esetükben a munka sokkal inkább személyre szabott, mint sem helyhez kötött (AUDIRAC, I. 2005).

A kreatív osztály városon belüli lokalizációjának megértéséhez egy pillanatra vissza kell kanyarodnunk oda, hogy a klasszikus fordi társadalomban a munkaerôt a fehérgalléros-kékgalléros csoportokra lehetett felosztani, s ezen csoportok általában a városi térben is elkülönültek egymástól. A kreatív korban a társadalom sokkal inkább a kreatív osztályra és az alacsony keresetú szolgáltató underclassra osztható fel, amelyet új kiszolgáló osztálynak is nevezhetünk. Előbbi magas szintű technikai tudással és elemzőképességgel, valamint társadalmi-kulturális know-how-val rendelkezik, míg utóbbi képességei informálisak és alulértékeltek, s gyakran alacsony státuszú, az ellátást és infrastruktúra múködését biztosító munkakörökben foglalkoztatottak körét jelenti. Viszont ezen szolgáltató underclassnak mindig elérhetőnek kell lennie a szolgáltatás helyén, így az általuk 
ellátott feladatok nem kiszervezhetők (outsourcingolhatók), mint a feldolgozóipari, vagy összeszerelő tevékenységek (GATTA, M. et al. 2009). Ez biztosítja ezen osztály stabil, hoszszú távú jelenlétét a kreatív városokban.

A kreatív gazdaság kibontakozásához tulajdonképpen az emberek két csoportjának kell jelen lennie a városban: a kreatív dolgozóknak és az új életformát, standardeket és fogyasztási kultúrát képviselő és követő embereknek (KLOUDOVÁ, J.-CHWASzCZ, O. 2013). Összességében azt mondhatjuk, hogy a kreatív mag inkább a városközpontokban található, míg a kreatív dolgozók számára vonzóbbak a városszéli és városközeli helyszínek (BoNTJE, M.-KEPSU, K. 2013), akár kisvárosok és rurális települések is (MADANIPOUR, A. 2011). A kreatív dolgozók tehát nemcsak a városközpontban telepednek le, hanem a városszéli új alcentrumokba és a városhatáron túli gyorsan fejlődő településekere is előszeretettel költöznek. Bár a kreatív foglalkoztatottak továbbra is a városokban találhatók, szlovéniai eredmények is arról tanúskodnak, hogy a kreatív foglalkozatottak térbeli mintázata - az új típusú életmódoknak és életpályamodelleknek köszönhetően - egyre inkább keveredik rurális és szuburbánus terekkel (KozinA, J.-CLIFTON, N. 2019).

A kreatív dolgozók a dzsentrifikáció úttörői közé tartoznak (COLE, D. B. 1987; LEY, D. 2003; Vivant, E. 2009). A kreatív rétegek egyúttal új életformákat és életstílusokat is magukkal hoznak (pl. yuppie-k, élettársi kapcsolatok, szivárvány családok stb.). A kreatív osztály leginnovatívabb rétege az újbohémok, akiknek a megjelenése a lakónegyedben különösen fontos, lévén olyan új kulturális fogyasztási szokásokat, életstílust, ízlésvilágot honosítanak meg, amely továbbterjedhet a kreatív osztály más csoportjaira és amely új lehetőségeket teremt a kulturális innováció és fogyasztás számára (LLOYD, R. 2006). Mivel a kreatív osztály ezen csoportja különösen vonzódik az egyedi építészeti értéket képviselő öreg épületekhez, amelyek a város történetéhez kapcsolódnak, kiemelt jelentőségük van a dzsentrifikációs folyamatokban. Általában új lendületet adnak a lakónegyed fejlődésének, új értékeket hoznak be a mindennapi életbe, de egyúttal a dzsentrifikáción keresztül a társadalmi egyenlőtlenségek és a szegregáció növekedéséhez is hozzájárulnak (YÁŃEZ, C. 2013). A probléma nem újkeletű, hiszen a tehetség vonzása és letelepedése érdekében indított dzsentrifikáció és kulturális megaprojektek negatív társadalmi hatásai már az 1980-as és 1990-es években felkeltették a kutatók érdeklődését (ZuKIN, S. 1995). CATungal, J. P. (2009) is felhívta a figyelmet arra, hogy a kreatív helyeket létrehozó beruházásoknak jelentős társadalmi és politikai költségei vannak.

Különösen a 2008-as gazdasági válság óta vált jellemzővé, hogy a kedvező fekvésû területeket ingatlanbefektetési céllal felvásárolják a beruházók, ami jelentősen megemelte az ingatlanárakat és bérleti díjakat. Ennek következményeképpen a bérlakásszektor ciklikusan újrarendeződik, amelyben a tehetôsebb kreatív réteg vesz részt (WANG, J.-ZHANG, L. 2019). A prémium kategóriájú területekre egyre több kreatív költözik be, legyen szó kreatív ipari vagy technológiai parkokról, vagy leromló lakónegyedek modern városrészekké alakításáról. Az általában alacsony keresetú kreatívok viszont csak addig tudnak a lakónegyedben élni, amíg az ingatlanpiac fel nem kapja a területet és fel nem értékelődnek az ingatlanok. Mivel a dzsentrifikáció mindig hasonló módon (körkörösen) zajlik, a múvészek és kreatívok gyakorlatilag mindig a városi növekedési gépezet fogaskerekei között találják magukat (WANG, J. et al. 2016), amit O’SulLivAN, F. (2014) ,artwashing” néven foglal össze.

\section{A projektalapú gazdaság hatásai a kreatív osztályra}

Egy projektalapú vállalkozás vagy szervezet múködtetése általában új menedzsmentszemléletet és irányítási eszközöket igényel, amelynek bevezetése történhet belül- 
ről is, a meglévő vállalati keretfeltételek között, de a menedzsment feladatokat sokkal gyakrabban alvállalkozói szerződés keretében exteralnizálják. Ezt különösen a nagyvállalkozások esetében gyakran a termelés kiszervezésével oldják meg (outsourcing), ami a munka individualizációjához és a munkafolyamatok depolitizálódásához, kazualitásához vezet (pl. egyéni vállalkozás, időszakos munkavállalás, szabadfoglalkozás). Mivel ez a folyamat a kreatív dolgozókat sokkal gyakrabban érinti, esetükben a munka és a munkahely bizonytalansága hatványozottan jelentkezik. A kreatív gazdaságban tehát egyre nő a bizonytalan munka és foglalkoztatás aránya, amire a munkaadók gyakran 0 órás szerződésekkel is ráerősítenek (WoODCOCK, J. 2014). Mindez az önfoglalkoztatás hamis illúzióját kelti. A kreatívok ezt a bizonytalanságot hálózatépítéssel, képességeik fejlesztésével és megbízási szerződések keresésével ellensúlyozzák. A munka utáni kocsmázás és közösségi élet a hálózati tőke építése és ápolása érdekében mintegy munkaköri kötelességgé válik. A rendezvények és események látogatása lehetőséget biztosít a kreatívok számára, hogy megmutassák magukat, imázsukat és reputációjukat növeljék (GiLL, R.-Pratt, A. 2008; Hesmondhalgh, D.-BAKer, S. 2010). A kreatívok lakónegyedükben gyökerező szakmai és személyes hálózata tehát egyben karrierjük forrása is (PRETECEILLE, E. 2010).

A projektalapú menedzsment célja alapvetően a munkaerőhöz köthető költségek csökkentése, nem pedig a kreatív folyamatok előtérbe helyezése. A piaci megfontolásokat tehát egyértelmúen a kreativitás elé helyezi. A kreatív munka az önkifejezés és munka olyan formája, amely kevésbé stabil és kiszámítható, mint a normál munka (CHRISTOPHERSON, S. 2013). Ennek következtében a kreatív dolgozók gyakran arra kényszerülnek, hogy alvállalkozói szerződés keretében bedolgozzanak egy cégnek vagy alkalmazotti státuszt keressenek ahelyett, hogy saját vállalkozást indítanának. Idő hiányában, vagy éppen az ügyfél vagy a közösség elismerésének bizonytalansága miatt gyakran meglévő sémákat alkalmaznak és kreativitásukat az ügyfél elvárásainak és elképzeléseinek rendelik alá. A kreatív dolgozó értéke napjainkban már sokkal inkább az ügyfél ismertségén és reputációján múlik, mint sem azon kreatív képességeken, amelyekkel a dolgozó rendelkezik. Piaci pozíciójuk megtartása és bővítése érdekében gyakran új képességeket sajátítanak el és multitask feladatmegoldást alkalmaznak saját kreatív projektek elindítása helyett (McRobBIE, A. 2002). A multitasking gyakran szükséges a sikerességhez és a vállalkozói szellemet jelzi, de a gyakori tevékenységváltás időhiányhoz vezet, ami nem kedvez a kreativitás kibontakoztatásának. A bevételek bizonytalansága, a rugalmas munkavégzés nem kedvez a családi életnek, így nem meglepő az sem, hogy a kreatívok között sokkal alacsonyabb a nők aránya (VIVANT, E. 2013). A kreatív gazdaságban tehát a kreatív dolgozóknak folyamatos bizonytalansággal kell szembenézniük, miközben vállalkozói mibenlétük állandó hálózatépítés, képességjavítás, önképzés, multitasking, egyéni vetélkedés, verseny, portfólió- és hírnévmenedzselés között zajlik. A kreatív dolgozók jövedelmének bizonytalansága ugyanakkor gyakran kizárja őket a hitelpiacról. Ily módon magasan képzett munkaerőhöz kapcsolódó bizonytalanság egyfajta prekariátus kibontakozásához vezethet a kreatív városokban.

A kreatívok rendkívül mobilisak annak érdekében, hogy a változó munkakörülményekhez és munkahelyekhez alkalmazkodjanak. A hálózatépítés ezen mobilitás központi elemévé válik, amelyhez a városközpont kínálja a legjobb feltételeket, helyeket és munkalehetőségeket. A modern és olcsó mobilitás lehetővé teszi a munkaerő számára a cirkuláris mobilitást olyan formában, hogy így nem kell családjuktól, rokonaiktól hosszú időre megválniuk. A munkaerő mobilitása hosszú távon a nem materiális, szellemi javak (tudás, innováció, kreativitás) áramlását és adaptációját is lehetővé teszi. A mobilitás ugyanakkor az agyelszívás folyamatát erôsítheti. 


\section{A coworking és a kreatív osztály kapcsolata}

A coworking fogalma viszonylag új, a 2000-es évek közepén jelent meg az USÁ-ban (FoERTSCH, C.-CAGNOL, R. 2013). A coworking erős ideológiai alapokon nyugszik, egyes szerzők a nyílt forrású mozgalom (open source movement) és a peer-to-peer kollaboratív gazdaság manifasztációjának tartják (LANGE, B. et al. 2010; BotsMAn, R.-Rogers, R. 2011), amely szorosan kapcsolódik a DIY (Do It Yourself - Csináld magad) kultúrához (WATERS-LYNCH, J. M. et al. 2015). A coworking lényege egyedül, de együtt dolgozni megosztott, kollaboratív munkahelyeken, amely a független, nem rutinszerú, kreatív munkavégzés szabadságát nyújta (SPINUZZI, C. 2012). A „közösség”, a közösségi lét a munka során meghatározó a coworking rendszerben dolgozók számára (SPINUZZI, C. et al. 2019). A közösségi lét, az interakciók, a rugalmas munkavégzés, az innovatív környezet és termelékenység mellett természetesen a coworking gazdasági okairól sem feledkezhetünk meg, hiszen a megosztott tér és eszközrendszer jelentősen csökkenti a munka költségeit (MERKel, J. 2015). WATER-LYNCH, J. M. és munkatársai (2016) hangsúlyozzák, hogy a coworking helyek különböznek a klasszikus munkahelymegosztástól, lévén itt a munkavégzés során a közösségi munkán és a társadalmi interakciókon van a hangsúly, ahol az együtt dolgozóknak a saját sikerességük érdekében jó szomszédoknak és partnereknek kell lenniük. Ilyen szempontból a coworking helyek jól egyesítik a közösségi létet a piaci tevékenységgel (SPINUZZi, C. et al. 2019).

A coworking rendszer kialakulásában meghatározó szerepe volt a tudásintenzív ágazatoknak és az infokommunikációs technológiáknak (2.ábra). Az IKT ugyanis alapvetően megnövelte a tudás mennyiségét, sokféleségét és összetettségét. Mivel ez a tudás kevésbé rutinszerú és hallgatólagos, megnőtt a személyes találkozás szerepe a hatékony kapcsolatok fenntartásában (CLIFTON, N.-FÜZI, A. et al. 2019).

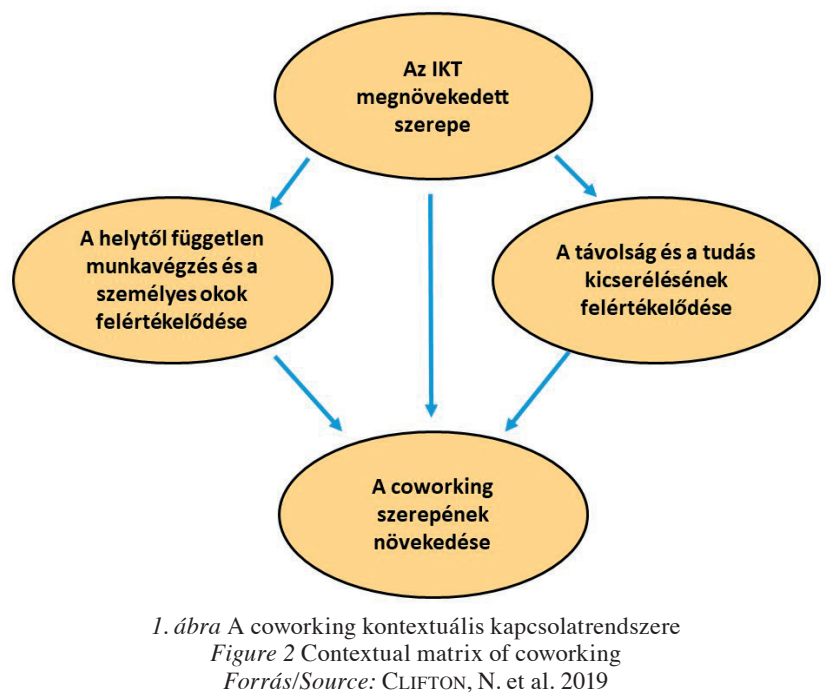

A coworking helyek tulajdonképpen nem egy teljesen új közösségi alapú szervezeti modellt jelentenek, sokkal inkább olyan hibrid struktúrák, amelyek piaci alapú tevékenységet is magukba foglalnak. A coworking helyek kialakulásához több társadalmi és gazdasági tényező vezetett: a városi munkaerőpiac átrendeződése, a munka eltolódása 
a tudásintenzív tevékenységek irányába, az internet és a digitális technológiák elterjedése a munkavégzésben. Mindez a munkahelyek területi átrendeződését is magával hozta. Maga a munkavégzés ugyanakkor egyre individuálisabb és izoláltabb lett (McRoBBIE, A. 2016).

A coworking eredetileg nem a hely kitüntetett szerepéról szólt, hanem sokkal inkább az informális kapcsolatokról és interakciókról, ami a hasonló életfilozófiájú dolgozók között zajlott. Idővel felismerték, hogy a folyamat jelentős szerepet játszik kreatív helyek kialakításában és a lakónegyedek megújításában. Napjainkban már nagyon sokféle coworking modell létezik az egyéni vállalkozók, KKV-k vagy nagyobb cégek számára együtt dolgozók részvételével. Ami azonban mindegyik modellben közös, az a szociális interakciók (a közösség) és az együttmúködés (tudásmegosztás, vagy kooperáció) (BRowN, J. 2017). A munkakollektívák (pl. coworking irodák) kialakulása a kreatív gazdaságban egyúttal nagyon fontos a személyes hálózatok fejlesztésében. A kreatív közösségek és munkahelyek szerveződése során ugyanis a kreatív dolgozók inspirációt kapnak munkatársaiktól.

A coworking munkahelyeken a potenciálisan együtt dolgozók köre viszonylag jól körülírható: ebbe a csoportba sorolhatók a szabadfoglalkozásúak, az önfoglalkoztatottak és a távmunkások. Bár a munka együtt, közösen folyik, motivációjuk nagyon sokféle lehet (Mitev, N. et al. 2018; SPInUZzi, C. 2012). A szabadfoglalkozásúak leggyakrabban a kreatív és média vonalon dolgoznak: újságírók, televízióban és rádióban dolgozók, kiadói tevékenységet folytatók, dizájnerek, fotósok, PR szakemberek, múvészek, zenészek (KITCHING, J. 2016). Gyakran digitális bohémok néven is említi őket a szakirodalom (Friebe, H.-LoBo, S. 2006), akik önmagukat a hálózat rugalmas, mobil és ad hoc csomópontjainak tartják. A foglalkozások sokszínú és változatos összetétele miatt a coworking helyek akkor múködnek hatékonyan, ha a dolgozók között coworking menedzserek múködnek közre (mediáció) (PARRINO, L. 2015).

\section{A digitális taylorizmus}

A témához szorosan kapcsolódik a tudásintenzív iparágakban dolgozók munkaerőpiaci helyzetének bemutatása. Korunk egyik nagy kihívása ezen a téren a digitális taylorizmus megjelenése. Az 1980-as és 1990-as években évente körülbelül 64\%-kal csökkentek a számítástechnika alkalmazásával összefüggő költségek, így az élet számtalan területén elterjedtek a számítógépek (Frey, C.-Osborn, M. 2013). Az 1990-es években még úgy tartották a közgazdászok, hogy a komputerizáció drámai módon növeli majd az emberiség termelékenységét (Rotman, D. 2013). A mesterséges intelligencia és az automatizálás azonban nem váltotta be a hozzá füzött reményeket, mert közepes és kiskeresetú dolgozók tömegei vesztették el a munkájukat, mikor a technológiai fejlődés miatt munkájuk elavult és a komputerizációból eredô hasznot néhány nagyvállalkozó fölözte le (BRYNJOLFSSON, E.-MCAFFEE, A. 2014). A „,nagy szétválásként” emlegetett folyamat rámutatott a technológiai haladás társadalmi veszélyeire és negatív hatásaira. A legrosszabbul fizetett szolgáltatások esetében viszont továbbra is megmaradt a fizikai munka szerepe, mert ezek a munkakörök nem igényelnek tanulást és a képességek fejlesztését, a gépesítés pedig jelentősen növelné a költségeket. Ugyanakkor nagyon sok középosztálybeli munkahelyet, például menedzseri vagy irodai munkaköröket érintett a számítógépek hatékonyabb munkavégzése, így a komputerizáció leginkább a középosztály munkanélkülivé válását hozta magával (FREY, C.-OSBORN, M. 2013). Ehhez az is hozzájárult, hogy míg korábban a számítógépek kizárólag nem kognitív jellegú feladatok végrehajtására voltak alkalmasak, a technológiai fejlődésnek köszönhetően viszont idővel kognitív feladatmegoldásra is alkalmassá váltak a számítógépek. A mesterséges intelligencia (AI) jelentős fejlődésen ment keresztül az elmúlt évtizedben és már kreatív feladatok végrehajtására is alkalmas. 
A kreatív munkavégzésre az ember által végzett munka utolsó bástyájaként tekintettek, amelyet a mesterséges intelligencia lassan képes felváltani és fokozatosan átveszi az emberi döntések szerepét a technológiaorientált szervezetekben (BOGOST, I. 2012).

2015-ben tûnt fel a digitális taylorizmus fogalma, amely a kreatív dolgozókat és menedzsereket egyre nagyobb arányban érinti. IRANI, L. (2015), valamint MoORE, P. és RoBinSON, A. (2015) amellett érvelnek, hogy a digitális technológiák visszahozták a taylorizmust a gazdaságba és a vállalatmenedzselés terén a digitális taylorizmus egyre nagyobb szerephez jut. BRown és szerzőtársai (2011) megállapítják, hogy a tudásalapú munka is egyre inkább rutinszerúvé válik, a kreatív és intellektuális feladatokat ugyanúgy, futószalagszerüen lehet végrehajtani. Abban a pillanatban, hogy a feladatvégrehajtást kodifikáltuk és digitalizáltuk, onnantól kezdve automatizálható a folyamat, tehát számítógépes döntési protokollokkal irányíthatjuk a feladat végrehajtását. A munka ily módon exportálhatóvá, cserélhetővé vagy helyettesíthetővé válik.

A digitális taylorizmus a taylorizmus több attribútumát is magában hordozza:

- Az összetett feladatokat egyszerú, standardizált részfeladatokra oszthatjuk fel;

- A dolgozók által végzett munka mérhetó és ellenőrizhető;

- A fizetést a teljesítményhez köthetjük.

Napjainkban a technológiai cégek is egyre gyakrabban alkalmazzák üzletvitelük során a taylorizmust. Példaként említhető az Amazon Mechanical Turk (mechanikus török, Kempelen Farkas sakkozógépe után) nevú internetes portálja, amely lehetôvé teszi a cégek számára, hogy az elvégzendő munkát kisebb részfeldatokra bontsák szét és ezeket a globális piacon szétosszák a részfeladatokat alacsony fizetség fejében végrehajtó emberek („törökök”) között. A munka ilyen tömeges kiszervezése (crowd-sourcing) lehetővé teszi, hogy a képzettséget és kreativitást igénylő összetett munkát képzettséget nem igénylő, rutinszerúen végrehajtható részegységekre bontsuk fel (pl. beszéd transzkriptálása, vagy tördelőszerkesztôi feladatok elvégzése) (KITTUR, A. et al. 2013). Mindeközben az összetettebb feladatok végrehajtása is egyre több technológiai háttértámogatást kap, ami lehetôvé teszi, hogy ezen feladatokat is a képzetlenebb munkaerő végezze el. A digitális taylorizmusnak a másik velejárója a megfigyelő rendszerek alkalmazása annak ellenőrzésére, hogy a dolgozók követik-e standardizált eljárásokat és teljesítik-e a termelésre vonatkozó időbeli elvárásokat. A tudás teljesítménye, annak végeredménye a mérhetőségen és a kodifikáción alapul, ebben viszont nem köszön vissza a tacit tudásáramlás, ami végső soron a kreatív dolgozók munkájának leértékelődéséhez vezet (TILL, C. 2014). A digitális taylorizmus lényegében egy alapvető ellentmondást hordoz magában: a neoliberális gazdaság kiemelt szerepet tulajdonít a tudásnak, innovációnak és a kreativitásnak, miközben a hatékonyság és teljesítménymaximalizálás érdekében a digitalizált rendszerek segítségével folyamatosan irányítja és kontrollálja a kreativitást, így éppen az emberi kreativitás kibontakozása ellenében hat (HOLFORD, W. D. 2019).

Humanitárius szempontból csak akkor lesz fenntartható a gazdaság, ha a technológiával helyettesíthetô foglalkozásokat jogi és társadalmi korlátozásoknak vetjük alá, illetve jobban átjárhatóvá tesszük a helyettesíthető és nem helyettesíthető foglalkozások körét. Rövidebb munkahét és munkaidő, az évi szabadság növelése lehetővé tenné a vállalkozók számára, hogy dolgozóik nagyobb részét megtartsák (TRACY, A. 2013). Másik megoldás lehet az elosztási rendszer újragondolása és a garantált minimum jövedelem bevezetésével enyhíteni lehetne a közép- és alsó osztály munkanélküliségének negatív hatásait. A kormányzat által mesterségesen létrehozott munkahelyek (munkaprogramok, állami projektek) is enyhíthetnek a munkanélküliség következményein. Hosszú távú biztos megoldást azonban az oktatási rendszer átalakítása jelenthet, ami felvértezheti az embereket az embergép hibrid gazdasághoz szükséges képességekkel (KIM, Y. J. et al. 2017). 


\section{A kreatív osztály elméletének kritikája}

Florida elméletét annak megjelenése óta számtalan kritika érte. Az egyik legfontosabb érv a kreatív osztály elméletével szemben az, hogy a kreativitás nem köthető foglalkozási szerepkörökhöz (MARKUSEN, A. 2006). Mint az ØSTBYE, S. és munkatársai (2018) megállapították, hogy a kreativitás sokkal inkább kapcsolható magához az emberhez, mint sem foglalkozáshoz, ennek ellenére a kreatív osztály fogalmát mégis inkább foglalkozási csoportokhoz kapcsolta Florida. GLAESER, E. (2005) is felveti a kérdést, hogy vajon mennyiben jelent újat a kreatív tőke (creative capital) fogalma a már régóta vizsgált humán tőkével (human capital) szemben, hiszen a kutatók - köztük Glaeser maga is - régóta hangoztatják, hogy egy város sikerességében nagy szerepe van a humán tőkének.

További probléma, hogy a kreatív osztály nem mutat társadalmi osztály jellemzőket, ily módon nem is értelmezhetó osztályként (PECK, J. 2005; SCOTT, A. J. 2006; MCGRANAHAM, D.-WoJAn, T. 2007). KRÄTKE, S. (2010) véleménye szerint még ha el is fogadjuk, hogy a kreatív osztályba sorolt csoportok azonosítása megfelelő módon történt, akkor sem értelmezhető a három különböző csoport vegyítése és egy kalap alatt történő vizsgálata. A Florida által kreatív osztályba sorolt emberek érdekei, felfogásuk és társadalmi-gazdasági jellemzői ugyanis nem azonosak. Florida elsősorban végzettségi kritériumok alapján sorolta be az egyes foglalkozásokat a kreatív osztályba a kreativitáshoz ténylegesen füződő kapcsolataik figyelmen kívül hagyásával, így kerülhettek egymás mellé olyan teljesen különböző foglalkozások, mint a múvész, építész, jogász vagy menedzser, akik nyilvánvalóan teljesen eltéró társadalmi és gazdasági preferenciákkal bírnak (FALUDI, J. 2019). A kreatív osztály elmélete azt sugallta, hogy a kreatív osztály képviselői egy vonzó kozmopolita városban szeretnének élni, holott a kreatív osztályként megjelölt szakemberek nagyon különböző életstílust és kultúrát követnek (MARKUSEN, A. 2006). A kreatív osztály elmélete igazándiból egy olyan dzsentrifikálódó, cirkuláló osztály támogatását részesíti előnyben, amelyik kevésbé kötődik a helyhez és a közösséghez és sokkal inkább individuumok csoportjaként értelmezhető, semmint egységes társadalmi osztályként.

Egyes tudományos munkák kritikával illették Floridát, hogy csak egy-egy „,trendi” városrész promótálását támogatja, ami azonban negatívan érintheti a régóta ott élő városiakat (PECK, J. 2005), vagy éppenséggel olyan városi átalakításokat támogat, amely a többség helyett csak bizonyos elit csoportoknak kedvez (PRATT, A. C. 2008). Ezt erősíti meg az a vélemény is, miszerint Florida alapvetően a kemény város imázs építést támogatja egyfajta puha éllel, amely például abban nyilvánul meg, hogy egy fogyasztás központú kulturális miliő létrehozását ösztönzi (PRATT. A.C. 2011). Tény, hogy a floridai elmélet kimondottan a várost irányítók körében lett népszerú, mivel a várospolitikusokra folyamatos nyomás nehezedett, hogy a várost eladhatóvá tudják tenni. Ez az elmélet pedig ,jól kommunikálható, pozitív városimázs hívószavakat" adott a városvezetés kezébe (CzIRFuSz, M. 2017). Ezzel kapcsolatban viszont HALL, P. (2004) arra hívja fel a figyelmet, hogy egy kreatív és innovatív város felépítése hosszú és lassú folyamat eredménye, nem megy egyik napról a másikra, mint arra Florida elméletéből következtethetnénk és a végeredmény sem mindig garantálható, vagy megelőlegezhető.

SCOTT, A. J. (2007) arra hívja fel a figyelmet, hogy a városban a munkaerópiac keresleti és kínálati oldala kölcsönhatásban vannak egymással, a folyamat elsődleges hajtóereje emiatt nem lehet egy bizonyos típusú munkaerő (kreatívok) egyoldalú beáramlása, hanem sokkal inkább a termelési rendszer komplex apparátusa a fejlődés motorja. SHARMUR (2007) vizsgálatai kanadai városokban is azt bizonyították, hogy a humán tőke azon városokba áramlik, amelyek gazdasági szerepe és teljesítménye nő és nem pedig fordítva. 
A 2006 és 2010 között zajlott ACRE-projekt (Accommodating Creative Knowledge in the Enlarged European Union) több olyan megállapítást is tett, amelyek rámutatnak az európai és az észak-amerikai kreatív osztály jellemzőinek különbségeire, illetve Florida elméletének relevanciájára (illetve annak hiányára) európai környezetben. Megállapítottuk, hogy az európai és amerikai kreatív osztály eltérő viselkedése, letelepedési jellemzői nagyrészt a mobilitásukban mutatkozó különbségekre vezethetők vissza. Az amerikai és az európai kreatívok mobilitási jellemzői, folyamatai és mintázatai ugyanis alapvetően különböznek egymástól. Az európai kreatív osztály nem olyan mobilis, mint az észak-amerikai, illetve mint Florida szerint lennie kellene. Az európai kreatív dolgozók nem túnnek mobilisabbnak a kontinentális átlagnál, mobilitási hajlandóságuk lényegesen alacsonyabb az amerikai kreatívokénál (HANSEN, H. K.-NyedomysL, T. 2009; MARTin-Brelot, H. et al. 2010). Ez részben kulturális okokra (pl. különböző nyelvek, eltérő kultúrák, nyitottság hiánya külföldiekkel szemben, a helyi viszonyok ismeretének hiánya stb.), másrészt intézményi okokra (pl. eltérő oktatási rendszer és tudásanyag, a külföldiek munkavállalását érintő egészségügyi és jogi környezet visszásságai, letelepedés bürokratikus jellemzői) vezethetők vissza.

Az ACRE-kutatás arra is rámutatott, hogy a legtöbb kreatív szakember többnyire abban a régióban (városban) él, ahol született, felnőtt és tanulmányait végezte, vagyis a nagy távolságokra történő mobilitás alárendelt szerepet játszik esetükben. Florida elmélete nem veszi figyelembe az emberi tényezőt, vagyis hogy a kreatív szakemberek is kötődhetnek más emberekhez és olyan helyekhez, ahol korábban éltek és dolgoztak. Az európai tehetség a személyes kapcsolatain és hálózati tőkéjén keresztül erősen kötődik a helyi munkaerő-piachoz. A „,személyes tényező”, amelyet Florida és követői elméletükben nem vettek figyelembe, nagyon fontos faktor európai szinten. Ezt az európai mobilitást vizsgáló más kutatások is alátámasztották (lásd GÁKOVÁ, Z.-DiJKSTRA, L. 2014). A mobilitási szokásokat figyelembe véve azt feltételezhetjük, hogy inkább a rövid idejú látogatások jellemzik az európai kreatív osztályt és így építik fel, illetve tartják fent hálózati kapcsolataikat. Azon kreatívok, akik a karrierjük során új lakhelyre költöztek, elsősorban kemény (alapvetően a munkához kapcsolódó) tényezők mentén döntöttek a hosszú távú elvándorlásról, esetükben a puha tényezők marginális szerepet játszottak. Florida elméletét tehát annyiban módosíthatjuk, hogy az új lakóhely (telephely) kiválasztása során az európai kreatívok kemény tényezők (pl. munkahelyek minősége) mentén döntenek egy adott település mellett, a puha faktorok pedig a településen belüli városrész kiválasztásában kerülnek az előtérbe. Úgy is fogalmazhatjuk, hogy a kemény tényezők a kreatívok bevonzásában, letelepedésében, a puha tényezők pedig a hosszú távú megtartásban játszanak kiemelkedő szerepet.

ØSTBYE, S. és szerzőtársai (2018) megállapították, hogy a kreatív foglalkozások más jellegú foglalkozásokat követnek és ez visszafelé is igaz, így egyfajta körforgás jellemzi a különböző foglalkozási csoportokat. Újabb amerikai és skóciai kutatások arról tanúskodnak, hogy elsősorban a munkalehetőségek és a jövedelem a munkaerő mozgatórugói, míg a környezetnek és ellátottságnak sokkal kisebb a szerepe (BEREITSCHAFT, B. 2017; Houston, D. et al. 2008). DARChen, S. és Tremblay, D-G. (2010) a tehetség mobilitásáról szóló kutatási eredményei is arról tanúskodnak, hogy a munkalehetőségek és a társadalmi tényezők fontosabb szerepet játszanak a tehetség migrációs folyamataiban, mint a társadalmi környezet (olyan puha tényezők, mint tolerancia, nyitottság stb.), vagy a hely minősége. A helyhez kapcsolható tényezők hosszú távon, a kreatív munkaerő megtartásában játszhatnak szerepet. Sokkal fontosabb lenne a kreatívok hosszú távú megtartása, mint letelepedésük preferálása, lévén hosszú távon a városrégiók inkább a kreatívok megtartásában lesznek állandó versenyben. 
Egyéb kutatások is tanúskodnak arról, hogy Florida valószínúleg túlértékelte a puha tényezők jelentőségét. MARLET, G. és WoERKENS, C. (2007) kutatásai holland városokban azt mutatták, hogy az esztétikus környezet és a természeti környezet pozitívan befolyásolják a kreatívok letelepedését, ugyanakkor a tolerancia nem bizonyult fontos tényezőnek. WEDEMAIER, J. (2010) a kreatív szektor foglalkoztatásra gyakorolt hatásait vizsgálta Németországban. Arra jutott, hogy a kreatív szektor növekedése és a foglalkoztatottság növekedése között pozitív összefüggés áll fenn, ugyanakkor nem talált bizonyítékot arra, hogy a helyi gazdaság diverzitása befolyásolta volna a növekedést.

Több kutató megállapította, hogy a városhierarchia befolyásolja a kreatívok mozgását, s különösen fontos szerepe lehet ennek olyan országokban, ahol erős a településhierachia (pl. Kelet-Európa, Svédország). LePAWsKy, J. (2010) arra a következtetésre jutott kanadai városok vizsgálatával, hogy a kreatívok mozgása korrelál a város településhierarchiában elfoglalt pozíciójával és sokkal inkább erre vezethetó vissza a kreatívok mozgása, mint sem a megavárosok kreatívokért vívott versenyére, mint azt Florida állította. CHOw, Y. F. (2017) ezt azzal egészítette ki, hogy a kínai kutatások szerint a politikai és geopolitikai kontextust is figyelembe kell venni a kreatív munkaerő mozgása során (az elmúlt években sok kreatív kínai költözött Hong Kongból Sanghajba és Pekingbe).

A kritikákra természetesen maga Florida is reagált: a tíz évvel korábban megjelent könyvének jubileumi, The rise of the creative class: Revisited címú második kiadásában tért ki a kreatív osztály elméletével kapcsolatos észrevételekre (FLORIDA, R. 2012). Elismeri, hogy a kreatív osztállyal kapcsolatban éppen az osztálytudat hiánya az egyik legnagyobb probléma, mivel ez az osztály egy messzemenőkig individualizált és atomizált társadalmi réteg, amelyre a liberális beállítottság ellenére kevésbé jellemző a szolidaritás és összetartás. Ugyanakkor a tradicionális gazdaság 2008-as világválságban kicsúcsosodó összeomlása után - álláspontja szerint - a kreatív osztálynak kulcsszerepe lesz a régi romjain felépülő új gazdasági rend kialakításában. Az általa vizionált kreatív kornak a nagy ígérete még nem teljesedett be. Továbbra is kiállt viszont a kreativitás meghatározó szerepe mellett a jövő gazdaságában. Hangsúlyozza, hogy a kreativitás minden emberben jelen van, s az újonnan kiformálódó kreatív társadalom célja éppen az lenne, hogy ezt az emberekben rejlő, gyakorlatilag korlátlanul és kimeríthetetlenül rendelkezésre álló kreativitást széles társadalmi rétegek számára kibontakoztassa és elérhetôvé tegye, felszabadítsa a kreatív energiákat és a tehetséget. Elismerte ugyanakkor, hogy a gazdasági változásokat a társadalmi változások lényegesen lassabban kísérik, s ez a hosszú átalakulási folyamat várhatóan kiélezi majd a társadalmi egyenlőtlenségeket és törésvonalakat nemcsak a kreatív osztály és más társadalmi osztályok között, hanem magán a kreatív osztályon belül is.

\section{Összefoglalás}

A kreatív osztály elmélete a 2000-es években jelent meg. Elterjedésében nagy szerepet játszott a kor gazdaságát meghatározó neoliberális szemlélet, amely nagy hangsúlyt helyezett a kreativitás, a tudás és az innováció meghatározó szerepére a nemzetgazdaságok fejlődésében. A kreatív osztály elmélete, összefonódva a kor másik meghatározó koncepciójával, a kreatív város elméletével, futótúzként terjedt el a városokban. A koncepció elterjedésében - különösen a kelet-közép-európai országokban a rendszerváltozás utáni átmenetben - nagy szerepe volt annak, hogy jól kitöltötte a gazdaságpolitikákban megjelenő koncepcionális ûrt. Az elmélet egyik legfontosabb erénye az volt, hogy felhívta a figyelmet a kreatív dolgozók gazdasági szerepére és átfogó koncepciót nyújtott 
a kreatív gazdaságban dolgozó rétegek munkaerőpiaci jellemzőire, társadalmi fejlődésére és múködésére.

A kreatív osztály elmélete a városfejlesztésben rövid távú perspektívát kínáló koncepció volt a helyi képességekre és adottságokra alapozó hosszú távú stratégiák kidolgozásával szemben. A kreatív osztály elmélete ugyanis gyors, előre gyártott, könnyen átvehetó és adaptálható várospolitika volt. Az elmélet azt sugallta, hogy mindenki nyerhet a koncepcióval, éppen ebben rejlett a sikere. Nem véletlen, hogy rendkívül népszerűvé vált a várospolitikusok, döntéshozók és kutatók körében. A kreatív osztály koncepciója mézesmadzagként mindenki számára a ,jóllakottság” érzését keltette, ugyanakkor radikális változtatásokra a várospolitikában és a városfejlesztésben nem voltak alkalmas (CHATTERTON, P. 2000).

A kreatív osztály elméletét megjelenése óta számtalan kritika érte, aminek hatására RICHARD FLORIDA áttekintette és részben módosította eredeti állításait. A koncepció jelentősége a neoliberális gazdaságpolitika hanyatlásával valószínúleg halványul, de kétségtelen, hogy a kreatív dolgozók, a kreatív emberek hosszú távon, a jövőben is a gazdasági fejlődés maghatározó csoportját fogják alkotni.

\title{
Köszönetnyilvánítás
}

A tanulmány az NKFIH/OTKA 128717. számú projekt támogatásával készült.

EGEDY TAMÁS

CSFK Földrajztudományi Intézet - BGE KVIK Turizmus Tanszék, Budapest egedy@gmx.net

\author{
IRODALOM
}

AUDIRAC, I. 2005: Information technology and urban form: Challenges to smart growth. - International Regional Science Review 28. pp. 119-145.

BEREITSCHAFT, B. 2017: Do "creative" and "non-creative" workers exhibit similar preferences for urban amenities? An exploratory case study of Omaha, Nebraska. - Journal of Urbanism: International Research on Placemaking and Urban Sustainability 10.2. pp. 198-216.

Bogost, I. 2012: Alien phenomenology or what it's like to be a thing. - University of Minnesota Press, London.

BONTJE, M.-KEPSU, K. 2013: Creative knowledge strategies for polycentric city-regions. - In: MUSTERD, S. - KoVÁCs, Z. (eds.) Place-making and policies for competitive cities. WileyBlackwell, Oxford. pp. 191-208.

Boschma, R.-Fritsch, M. 2009: Creative Class and Regional Growth: Empirical Evidence from Seven European Countries. - Economic Geography 85. 4. pp. 391-423.

Botsman, R.-Rogers, R. 2011: What's Mine Is Yours. - Collins, New York.

Brown, J. 2017: Curating the "Third Place"? Coworking and the mediation of creativity. - Geoforum 82. pp. 112-126.

Brown, P.-Lauder, H.-Ashton, D. 2011. The global auction: The broken promise of education, jobs and incomes. - Oxford University Press Inc. New York.

Brynjolfsson, E.-MCAfEe, A. 2014. Second machine age: Work, progress, and prosperity in a time of brilliant technologies. - W. W. Norton-Company.

Catungal, J.P.-Leslie, D.-Hit, Y. 2009: "Geography of Displacement in the Creative City. The Case of Liberty Village Toronto". - Urban Studies 46. 5-6. pp. 1095-1114.

Chatterton, P. 2000. Will the real creative city please st and up? - City 4. 3. pp. 390-397.

CHOw Y. F. 2017: "Exploring creative class mobility: Hong Kong creative workers in Shanghai and Beijing". - Eurasian Geography and Economics 58. 4. pp. 361-385.

Christopherson, S. 2013: 'Hollywood in decline? US film and television producers beyond the era of fiscal crisis'. - Cambridge Journal of Regions, Economy and Society 6. pp. 141-157. 
Clifton, N.-Cooke, P:-Høgni Kalsø, H. 2012: Towards a Reconciliation of the 'Context-less' with the 'Space-less'? The Creative Class across Varieties of Capitalism: New Evidence from Sweden and the UK. - Regional Studies

Clifton, N.-FüZI, A.-Loudon, G. 2019: Coworking in the digital economy: Context, motivations, and outcomes. - Futures

Cole, D. B. 1987: Artists and urban redevelopment. - The Geographical Review 77. 4. pp. 391-407.

CzIRfusz, M. 2017: Creativity and culture in reproducing uneven development across Central and Eastern Europe. - In: LuX. G.-Horváth Gy (eds.): The Routledge Handbook to Regional Development in Central and Eastern Europe. - Routledge, London-New York. pp. 106-119.

Darchen, S.-Tremblay, D-G. 2010: What attracts and retains knowledge workers/students: The quality of place or career opportunities? The cases of Montreal and Ottawa. - Cities 27. pp. 225-233.

ERNST - Young 2015: Cultural times: The first global map of cultural and creative industries. - https://www. ey.com/Publication/vwLUAssets/ey-cultural-times-2015/\$FILE/ey-culturaltimes-2015.pdf

FALUDI, J. 2019: The paradigm of the creative class in regional and urban development revisited. An overview. - Corvinus Journal Of Sociology and Social Policy 10. 2. pp. 167-188.

FLORIDA, R. 2002: The rise of the creative class: and how it is transforming work, leisure, community and everyday life. - Basic Books, New York.

Foertsch, C.-Cagnol, R. 2013: The History of Coworking in a Timeline. - http://www.deskmag.com/en/ the-history-of-coworking-spaces-in-atimeline d 3. pp. 187-208.

Frey, C.-OsBorne, M. 2013: The future of employment: How susceptible are jobs to automation? University of Oxford. - http://www.oxfordmartin.ox.ac.uk/downloads/academic/The_Future_of_Employment.pdf

FRIEBE, H.-LOBO, S. 2006: Wir nennen es Arbeit: die digitale Bohème oder: Intelligentes Leben jenseits der Festanstellung. - Heyne.

GÁkOVÁ, Z.-DiJKSTRA, L. 2014: Labour mobility between the regions of the EU-27 and a comparison with the USA. Regional Focus, Regional Policy. - European Commission, Brussels.

GatTA M.-Boushey H.-ApPelbaum E. 2009: High-touch and here-to-stay: future skills dem ands in US low wage service occupations, Sociology - Journal of the British Sociological Society 43. pp. 968-989.

GILL, R.-PRATT, A. 2008: In the social factory? Immaterial Labour, Precariousness and Cultural work. - Theory, Culture and Society, 25. 7-8. pp. 1-30.

GLAESER, E. 2005: Review of Richard Florida's The Rise of the Creative Class. - Regional Science and Urban Economics 5. pp. 593-596.

HaAse, A.-Kabisch, S.-Steinführer, A.-BouZarovski, S.-Hall, R.-Ogden, P. 2010: Emergent spaces of reurbanisation: exploring the demographic dimension of inner-city residential change in a European setting. - Population Space and Place 16. pp. 443-463.

Hall, P. 2004: Creativity, culture, knowledge and the city. - Built Environment 3. pp. 256-258.

Hansen, H.K.-Niedomysl, T. 2009: Migration of the Creative Class: Evidence from Sweden. - Journal of Economic Geography 9. 2. pp. 191-206.

Hesmondhalgh, D. - BAKer, S. 2010: “A very complicated version of freedom”: Conditions and experoiences of creagive labour in three cultural industries.

Higgs, P.-Cunningham, S.-BAKhshi, H. 2008: Beyond the creative industries: Mapping the creative economy. - London.

Holford, W.D. 2019: The future of human creative knowledge work within the digital economy. - Futures 105. pp. 143-154.

Houston, D.-Findlay, A.-HARrison, R.-Mason, C. 2008: "Will attracting the "creative class" boost economic growth in old industrial regions? A case study of Scotland. Geografiska Annaler: Series B. - Human Geography, 90, 2. 133-149.

IRANI, L. 2015: Difference and dependece among digital workers: The case of amazon mechanical Turk. - South Atlantic Quarterly 114. 1. pp. 225-234

KAO, J. 1999: Ötletgyár avagy a kreatív szervezet. - SHL Hungary Kft. Budapest.

KIM, Y.J.-KIM, K.-LEE, S. 2017: The rise of technological unemployment and its implications on the future macroeconomic 1 andscape. - Futures 87. pp. 1-9.

Kitching, J. 2016: Exploring the UK Freelance Workforce in 2015. Association of Independent Professionals and the Self Employed, Small Business Research Centre - Kingston University, London. 43 p.

Kittur, A.-Nickerson, J. V.-Bernstein, M. S.-Gerber, E. M.-Shaw, A.-Zimmerman, J.-Lease, M. -Horton, J. J. 2013: The Future of Crowdwork. San Antonio, Texas, USAThe Future of Crowdwork. - CSCW 2013 Conference.

Kloudová, J.-Chwaszcz, O. 2013: The Evaluation of Creativity Effects on the Regional Development in the Czech Republic. International Journal Of Mathematical Models and Methods. - Applied Sciences 4. 7. pp. 404-411. 
KozinA, J.-CLIFTON, N. 2019: City-region or urban-rural framework: what matter more in underst anding the residential location of the creative class? - Acta geographica Slovenica 59. 1. pp. 141-157.

KRÄTKE, S. 2010: 'Creative Cities' and the Rise of the Dealer Class: A Critique of Richard Florida's Approach to Urban Theory. - International Journal of Urban and Regional Research 34. 4. pp. 835-853.

LANGe, B.-Pradel, I.-Miquel, M.-Garnizov, V. 2010: New governance, new geographic scales, new institutional settings. In: Musterd S.-MurIE A. (eds.) Making competitive cities Chichester, - John Wiley and Sons, Chichester. pp. 306-326.

LENGYEL B.-SÁGVÁRI B. 2009: Kreatív foglalkozások és regionális tudásbázis: fogalmak, folyamatok és területi összefüggések. - Tér és Társadalom 23. 4. pp. 1-26.

LePawsky, J.-Phan, Ch.-Greenwood, R. 2010: "Metropolis on the margins: talent attraction and retention to the St. John's city-region". - The Canadian Geographer 54. 3. pp. 324-346.

LEY, D. 2003: Artists, aestheticisation and the field of gentrification. - Urban Studies 40. 12. pp. $2527-2544$.

LLOYD, R. 2006: Neo-bohemia: Art and commerce in the postindustrial city. - London: Routledge.

MadAnipour, A. 2011: Knowledge economy and the city: Spaces of knowledge. - New York.

MARKuSEn, A. 2006: Urban development and the politics of a creative class: evidence from the case study of artists. - Environment and Planning A 38. 10. pp. 1921-1940.

Marlet, G.-Woerkens, C. 2007: The Dutch creative class and how it fosters urban emploment growth. Urban Studies 44. 13. pp. 2605-2626.

Martin-Brelot, H.-Grossetti, M.-Eckert, D.-Gritsai, O.-Kovacs, Z. 2010: The spatialmobility of the 'creative class': A European perspective. - International Journal of Urban and Regional Research 34. 4. pp. 854-870.

McGranahan, D.- Wojan, T. 2005: Recasting the Creative Class to Examine Growth Processes in Rural and Urban Counties. - Regional Studies 41. 2. pp. 197-216.

McRobile, A. 2002: Clubs to companies: notes on the decline of political culture in speeded up creative worlds. - Cultural Studies 16. 4. pp. 516-531.

McRobbie, A. 2016: Be Creative: Making a Living in the New Culture Industries. - John Wiley and Sons, Chichester.

MERKEL, J. 2015: Co-working in the city. Ephemera 15. 1. pp. 121-139.

Mitev, N.-De Vaujany, F.-LaniRay, P.-Bohas, A.-Fabbri, J. 2018: Co-working spaces, collaborative practices and entrepreneurship. In K. RIEMER-S. SCHELlHAMMER (eds.) Collaboration in the digital age Springer Verlag 2018.

Moore, P.-Robinson, A. 2015: The quantified self: What counts in the neoliberal workplace. New MediaSociety online first.

O’Sullivan, F. 2014: “The Pernicious Realities of 'Artwashing'. - http://www.citylab.com/housing/2014/06/ the-pernicious-realities-of-artwashing/373289/

Østbye, S.-Moilanen, M.-Tervo, H.-Westerlund, O. 2018: "The creative class: do jobs follow people or do people follow jobs?". - Regional Studies 52. 6. pp. 745-755.

PARRINO,L. 2015: Coworking: assessing the role of proximity in knowledge exchange.-Knowledge Management Research Practice 13. pp. 261-271.

PECK, J. 2005: Struggling with the creative class. - International journal of Urban and Regioal Resarch 29. 4. pp. $740-770$.

PRATT, A.C. 2008: Creative cities: the cultural industries and the creative class. - Geografiska annaler: Series B-Human geography 90.2. pp. 107-117.

Preteceille, E. 2010: The fragile urban situation of cultural producers in Paris. - City, Culture and Society, 1. 1. pp. 21-26.

Rotman, D. 2013: How technology is destroying jobs. - MIT Technology Review - http://www.technologyreview.com/featuredstory/515926/how-technology-is-destroying-jobs/ Letöltve 2020. április 3.

ScotT, A. J. 2006: Creative cities: Conceptual issues and policy questions. - Journal of Urban Affairs, 28 1. 1-17.

ScotT, A. J. 2007: Capitalism and urbanization in a new key? The cognitive-cultural dimension. - Social Forces 85. pp. 1465-1482.

Slach, O.-KoutskÝ, J.-NovotnÝ, J.-ŽEnkA, J. 2013: Creative industries in the Czech Republic: A spatial perspective. - Ekonomie a Management 16.pp. 414-29.

SPINUZZI, C. 2012: Working alone together co-working as emergent collaborative activity. - Journal of Business and Technical Communication 26. 4. pp. 399-441.

Spinuzzi, C.-Bodrozic, Z.-Scaratti, G.-Ivaldi, S. 2019: "Coworking is about community" but what is "community" in coworking? - Journal of Business and Technical Communication 33. 2. pp. 112-140.

Stolarick, K.-CuRrid-Halkett, E. 2013: Creativity and the crisis: The impact of creative workers on regional unemployment. - Cities 33. pp. 5-14.

StorPer, M.-ScotT, A. J. 2009: Rethinking human capital, creativity and urban growth. - Journal of Economic Geography 9. pp. 147-167. 
TILL, C. 2014: Exercise as labour: Quantified self and the transformation of exercise into labour. - Societies 4.3. pp. 446-462.

TraCy, A. 2013: The '40 hours a week or less' theory gains momentum. - Inc. Magazine - http://www.inc. com/abigail-tracy/why-you-should-work-less-and-unplug-more.html

Vivant, E. 2009: How underground culture is changing Paris. - Urban Research and Practices 2. 1. pp. 36-52.

Vivant, E. 2013: Creatives in the city: Urban contradictions of the creative city. - City, Culture and Society 4. pp. 57-63.

WANG, J.-OAKes, T.-YANG, Y. (eds.) 2016: Making Cultural Cities in Asia: Mobility, assemblage, and the politics of aspirational urbanism. - Routledge, London.

WANG, J.-ZHANG, L. 2019: The centripetal and centrifugal forces at work: mobility of the creative workforce. - In: KonG, L.-DoIs, A. D. (eds.) Geographies of Creativity. - Edward Elgar, London.

WATERs-Lynch, J.M.-PotTs, J.-Butcher, T.-Dodson, J.-Hurley, J. 2015: Coworking: A Transdisciplinary Overview. -

Wedemaier J. 2010: The Impact of the Creative Sector on Growth in German Regions. - European Planning Studies 18. 4. pp. 505-520.

Woodcock, J. 2014: Precarious workers in London: New forms of organisation and the city. - City 18. 6. pp. $776-788$.

YÁŃEZ, C. J. N. 2013: Do 'creative cities' have a dark side? Cultural scenes and socioeconomic status in Barcelona and Madrid 1991-2001 - Cities 35. pp. 213-220.

ZANDiATASHBAR, A.-HAMidi, S.-Foster, N. 2019: High-tech business location, transportation accessibility, and implications for sustainability: Evaluating the differences between high-tech specializations using empirical evidence from U.S. booming regions. - Sustainable Cities and Society 50.

ZukIN, S. 1995: The Cultures of Cities. - Blackwell, Cambridge. 